\title{
Aplikasi Perhitungan Komponen Pasif Elektronika Berbasis Android
}

\author{
Ade Setiawan', Sandra Dewi Saraswati $^{2}$, Waeisul Bismi ${ }^{1}$ \\ ${ }^{1}$ Teknik dan Informatika, Universitas Bina Sarana Informatika, Jakarta, Indonesia \\ ${ }^{2}$ Teknik Informatika, STMIK Nusa Mandiri, Jakarta, Indonesia \\ Email: ade.dtx@bsi.ac.id, sandra.sww@nusamandiri.ac.id,waeisul.wbn@bsi.ac.id \\ Submitted 21-04-2020; Accepted 25-04-2020; Published 26-04-2020
}

\begin{abstract}
Abstrak
Perkembangan handphone yang semakin pesat baik itu berupa hardwarenya yang dulu menggunakan keypad sekarang menjadi touch screen, dan dari softwarenya yang umumnya masih menggunakan OS symbian dan java, kini hampir semua orang beralih ke OS android Ini dikarenakan OS android, memiliki banyak macam keunggulan dari segi aplikasinya. Banyak yang memanfaatkan aplikasi android yang diantaranya adalah untuk membaca $\mathrm{Al}$ qur'an, membaca kitab maulid, belajar memasak, memesan makanan secara online bahkan memesan jasa pelayanan transportasi. Mereka semua pengguna hanphone android dimudahkan segala aktivitas sehari-harinya dengan gadget yang dimilikinya. Untuk itulah penulis mencoba membuat aplikasi android yang berguna di dalam pembelajaran ilmu elektronika. Tentu jika kita bahas ilmu elektronika, maka penjabarannya meluas, dengan ini penulis membatasi bahwa aplikasi yang penulis buat adalah aplikasi yang membahas komponen pasif elektronika dasar. Targetnya adalah aplikasi ini bisa digunakan untuk siswa SD, SMP, SMA, SMK, bahkan perguruan tinggi yang tentunya sesuai jurusannya. Tidak hanya itu aplikasi yang penulis buat bis a jika digunakan untuk kalangan teknisi reparasi perangkat elektronika. Dengan ini diharapkan pembuatan aplikasi android dengan judul aplikasi pengetahuan dan perhitungan komponen pasif elektronika dasar berbasis android bisa membantu proses belajar mengajar di dunia pendidikan yang tentunya dari tingkatan SD, SMP, SMA, SMK, dan perguruan tinggi serta menjadi solusi pemanfaatan gadget yang lebih cerdas, tepat dan edukatif.
\end{abstract}

Kata Kunci: Android, Resistor, Java.

\begin{abstract}
Increasingly rapid development of mobile phone whether it is the hardware that is used to using a keypad is now a touch screen, and from software are generally still use Symbian OS and Java, now almost everyone is switching to Android OS. This is because the Android OS, has many kinds of advantages in terms of application. Many who use android application which of them is to recite the Qur'an, read a book maulid, learn to cook, order food online even ordered transportation services. They all android phone users should be eased all his daily activities with its gadgets. For this reason the author tries to create android apps that are useful in science learning electronics. Certainly if we discuss the science of electronics, the elaboration widespread, with these authors restrict that application that the author is an application that addresses the basic electronic passive components. The target is this application can be used for elementary, junior high, high school, vocational school, even college course in accordance department. Not only was the application that the author made can be when used for the repair technician electronics devices. With this expected to manufacture android application with the title of the application of knowledge and calculation of passive components basic electronics based on Android can help the learning process in the world of education that certainly from the level of elementary, junior high, high school, vocational and higher education as well as a solution the use of gadgets smarter, precise and instructive.
\end{abstract}

Keywords: Passive Electronic Component Based Applications Android

\section{PENDAHULUAN}

Perkembangan handphone yang semakin pesat baik itu berupa hardwarenya yang dulu menggunakan keypad sekarang menjadi touch screen, dan dari softwarenya yang umumnya masih menggunakan OS symbian dan java, kini hampir semua orang beralih ke OS android. Ini dikarenakan OS android, memiliki banyak macam keunggulan dari segi aplikasinya. Banyak yang memanfaatkan aplikasi android yang diantaranya adalah untuk membaca Al qur'an, membaca kitab maulid, belajar memasak, memesan makanan secara online bahkan memesan jasa pelayanan transportasi. Mereka semua pengguna hanphone android dimudahkan segala aktivitas sehari-harinya dengan gadget yang dimilikinya. Hal ini mendorong penulis ingin membuat aplikasi yang berguna untuk masyarakat umum.

Maka dengan segala macam aplikasi yang bermunculan, penulis ingin membuat aplikasi yang berguna di dalam pembelajaran ilmu elektronika. Di bidang ilmu elektronika sendiri, tingkatan pembelajarannya meliputi tingkat SD, SMP, SMA, SMK dan sampai tingkat universitas. Oleh karena itu pembahasan ilmu elektronika yang akan penulis implementasikan dalam bentuk aplikasi sifatnya adalah ilmu elektronika umum. Adapun pembelajaran yang akan dibuat penulis adalah seputar tentang pengenalan dan perhitungan komponen pasif elektronika yang meliputi fixed resistor, SMD resistor, fixed kapasitor dan SMD kapasitor.

Untuk memperkuat penelitian ini, penulis mengambil dua jurnal referensi yang dijadikan teori dasar untuk materi yang berhubungan dengan komponen. Menurut Hariyanto Didik (2009) menjelaskan pengertian resistor sebagai berikut: Resistor adalah komponen dasar elektronika yang digunakan untuk membatasi jumlah arus yang mengalir dalam satu rangkaian. Sesuai dengan namanya resistor bersifat resistif dan umumnya terbuat dari bahan karbon[3]. Dari hukum Ohms diketahui, resistansi berbanding terbalik dengan jumlah arus yang mengalir melaluinya. Satuan resistansi dari suatu resistor disebut Ohm atau dilambangkan dengan simbol W (Omega). 


\section{METODE PENELITIAN}

\subsection{Model Pengujian}

Pengujian software dilakukan untuk mencegah terjadinya kesalahan dalam program dengan metode-metode tertentu. Di dalam pengujian software terdapat beberapa metode [6], diantaranya :

1. Metode Pengujian Black Box

Pengujian Black Box adalah pengujian yang dilakukan terhadap interface tertentu untuk menguji bahwa fungsi-fungsi interface tersebut bekerja dengan baik.

2. Metode Pengujian White Box

Pengujian White Box merupakan pengujian yang dititik beratkan kepada prosedur cara program tertentu bekerja dengan memberikan suatu kondisi. Menurut Sukamto dan Shalahuddin (2013) Metodologi berorientasi objek adalah suatu strategi pembangunan perangkat lunak yang mengorganisasikan perangkat lunak sebagai kumpulan objek yang berisi data dan oprasi yang diberlakukan terhadapnya[5].

Metode berorientasi objek meliputi rangkaian aktivitas analisis berorientasi objek, perancangan berorientasi objek, pemrograman berorientasi objek dan pengujian berorientasi objek, metode berorientasi objek banyak dipilih karena metode lama banyak menim-bulkan masalah seperti adanya kesulitan pada saat mentransformasikan hasil dari satu tahapan pengembangan ketahap berikutnya[6].

\subsection{UML (Unifield Modeling Language)}

Menurut Sukamto dan Shalahuddin (2013) UML adalah suatu yang salah, tapi perlu ditelaah dimanakah UML digunakan dan hal apa yang ingin divisualkan, pada perkembangan teknik pemrograman berorientasi objek, muncullah sebuah standarisasi bahasa pemodelan untuk pembangunan perangkat lunak yang dibangun dengan menggunakan teknik pemrograman yang berbasis objek yaitu Unifield Modeling Language (UML). UML muncul karena adanya kebutuhan pemodelan visual untuk mengimplmentasikan,menggambarkan,membangun, dan dokumentasi dari sistem perangkat lunak[5]. UML merupakan bahasa visual untuk pemodelan dan komunikasi mengenai sebuah sistem dengan menggunakan diagram dan teks-teks pendukung.

a) Class Diagram.

Menggambarkan struktur sistem dari segi pendefinisian kelas-kelas yang akan dibuat untuk membangun sistem.

b) Use Case Diagram.

Mendeskripsikan sebuah intraksi antara satu atau lebih aktor dengan sistem informasi yang akan dibuat, use case digunakan untuk mengetahui fungsi apa saja ada didalam sebuah sistem informasi dan siapa saja yang berhak menggunakan fungsi-fungsi itu.

c) Activity Diagram.

Menggambarkan workflow (aliran kerja) atau aktivitas dari sebuah sistem atau proses bisnis. Yang perlu diperhatikan disini adalah bahwa diagram aktivitas menggambarkanaktivitas sistem bukan apa yang dilakukan aktor jadi aktivitas yang dapat dilakukan sistem.

d) Sequence Diagram.

Mendeskripsikan waktu hidup objek dan message yang dikirimkan dan diterima antar objek. Oleh karena itu untuk menggambarkan diagram sekuen makan harus diketahui objek-objek yang terlibat dalan use case beserta metodemetode yang dimiliki kelas yang diimplementasikan menjadi objek.

\subsection{Android ADT}

Merupakan plugin di eclipse yang harus kita instal sehingga android SDK yang sudah ada dapat dihubungkan dengan DE Eclipse yang kita gunakan sebagai tempat coding aplikasi android nantinya[1][4][7].

\section{HASIL DAN PEMBAHASAN}

\subsection{Kebutuhan Hardware dan Software}

Perancangan aplikasi ini menggunakan hardware dan software diantaranya adalah notebook PC, windows 7, adobe photoshop 7.0, eclips indigo, ADT (Android Development Tools) 18.0.0 Plugin, android SDK (Software Development Kit) dan java JDK (Java Development kit).

Dalam aplikasi pembuatan aplikasi ini penulis menggunakan beberapa metode diantaranya:

1) Metode Observasi yaitu perbandingan terhadap aplikasi elektronika yang sudah dibuat sebelumnya.

2) Metode Studi Kepustakaan

yaitu Pengambilan data dengan cara mengambil materi-materi yang berhubungan dengan judul karya ilmiah melalui buku-buku dan jurnal.

Alat dan bahan yang digunakan untuk pembuatan Aplikasi Perhitungan Komponen Pasif Elektronika Berbasis Android adalah sebagai berikut :

1. Komponen Hardware. 
Komputer yang digunakan penulis mempunyai klasifikasi sebagai berikut.

1) Vendor : Notebook PC

2) Tipe : $X 43 U$

3) HDD : $500 \mathrm{~GB}$

4) RAM : 2 GB

5) Proccesor : AMD E-450 APU (Dual Core)

6) Graphic : Radeon (tm) HD Graphic $1.6 \mathrm{GHz}$

Dalam pembuatan apikasi android minimal Dual core karena akan berpengaruh terhadap pembuatan virtual android yang akan digunakan.

2. Komponen Software

Komponen perangkat lunak yang digunakan untuk membuat aplikasi tersebut adalah.

1) Windows 7

Sistem operasi yang digunakan untuk membuat aplikasi yang akan dibuat.

2) Eclipse

Eclipse merupakan tempat kita mebuat projek aplikasi android dan ada beberapa device yang yang harus diinstall dieclipse diantaranya:

a) Android SDK

Merupakan alat bantu dan API dalam mengembangkan aplikasi pada platform android menggunakan bahasa pemrograman java.

b). Java JDK

Java JDK digunakan untuk plugin bahasa pemrograman java.

c). Adobe Photoshop 7.0

Software yang diguakan untuk mendesain tampilan berupa gambar-gambar yang akan digunakan dalam program android.

3. Aplikasi

Aplikasi yang digunakan adalah aplikasi yang berbasis android sehingga program tersebut dapat digunakan untuk menjalankan fungsinya.

4. Input/output

Input/output yang digunakan adalah input penggunaan dari interface android itu sendiri yang menghasilka output berdasarkan dari input yang dimasukan.

Dalam pembuatan aplikasi ini, sesuai dengan rumus untuk menghitung salah satu komponen yaitu berupa resistor, berikut algoritmanya[2][8]:

$\Omega=\mathrm{D} 1+\mathrm{D} 2 * \mathrm{D} 3$

Keterangan :

$\Omega \quad=$ Nilai Hambatan $(\Omega)$

D1 = Nilai Pada Gelang 1

D2 = Nilai Pada Gelang 2

D3 = Nilai Pada Gelang 3

\subsection{Perancangan UML}

Dalam penulisan penelitian ini, penulis menggunakan aplikasi UML dalam pemodelan programnya yaitu terdiri dari use case diagram, activity diagram, sequence diagram, class diagram dan deployment diagram. Lalu penulis menggunakan tools eclipse indigo dalam pembuatan desain aplikasi.

a. Use case

Berikut merupakan rancangan dari use case diagram.

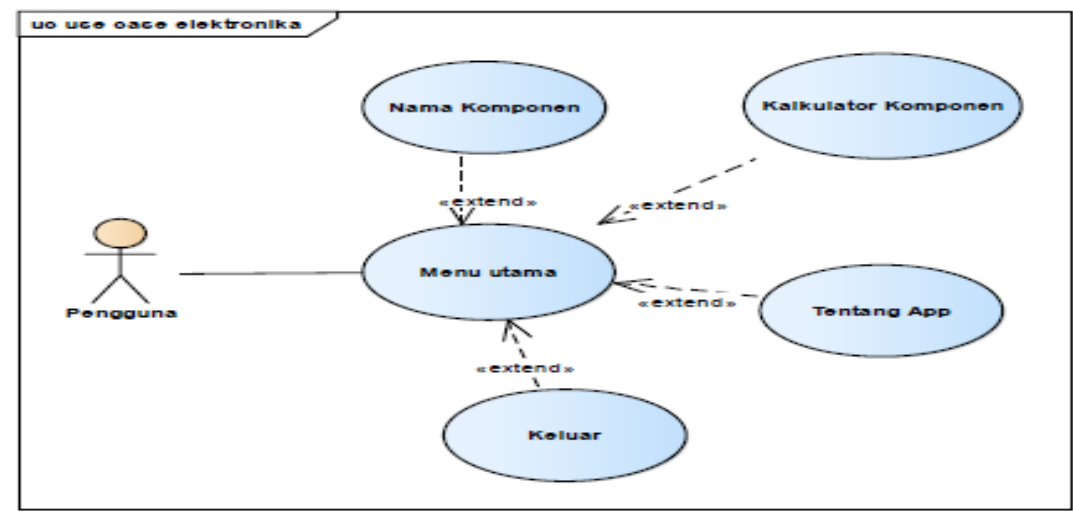

Gambar 2. Use Case Diagram 
b. Activity Diagram

Berikut merupakan rancangan dari activity diagram.

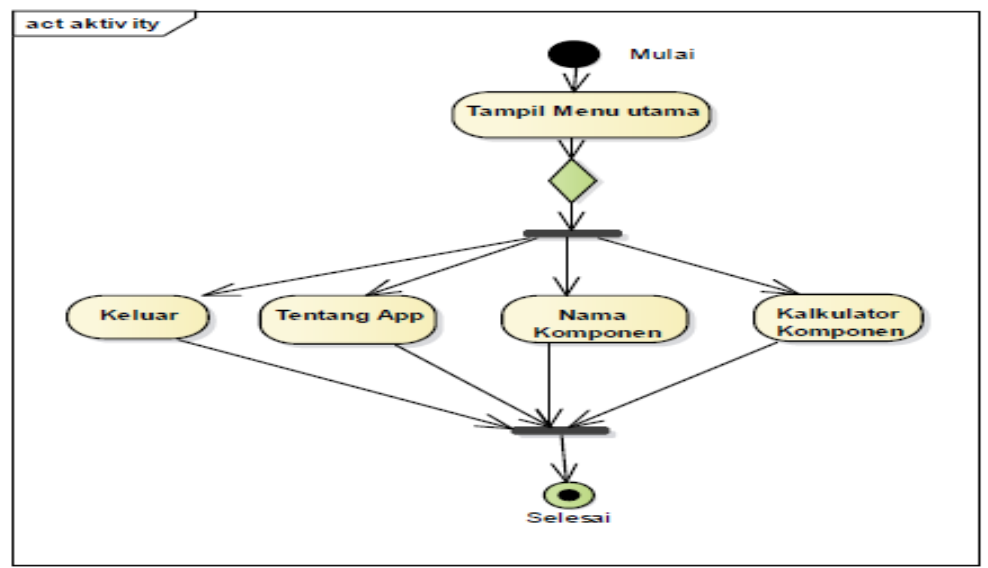

Gambar 3. Activity Diagram

c. Sequence Diagram

Berikut merupakan rancangan dari sequence diagram.

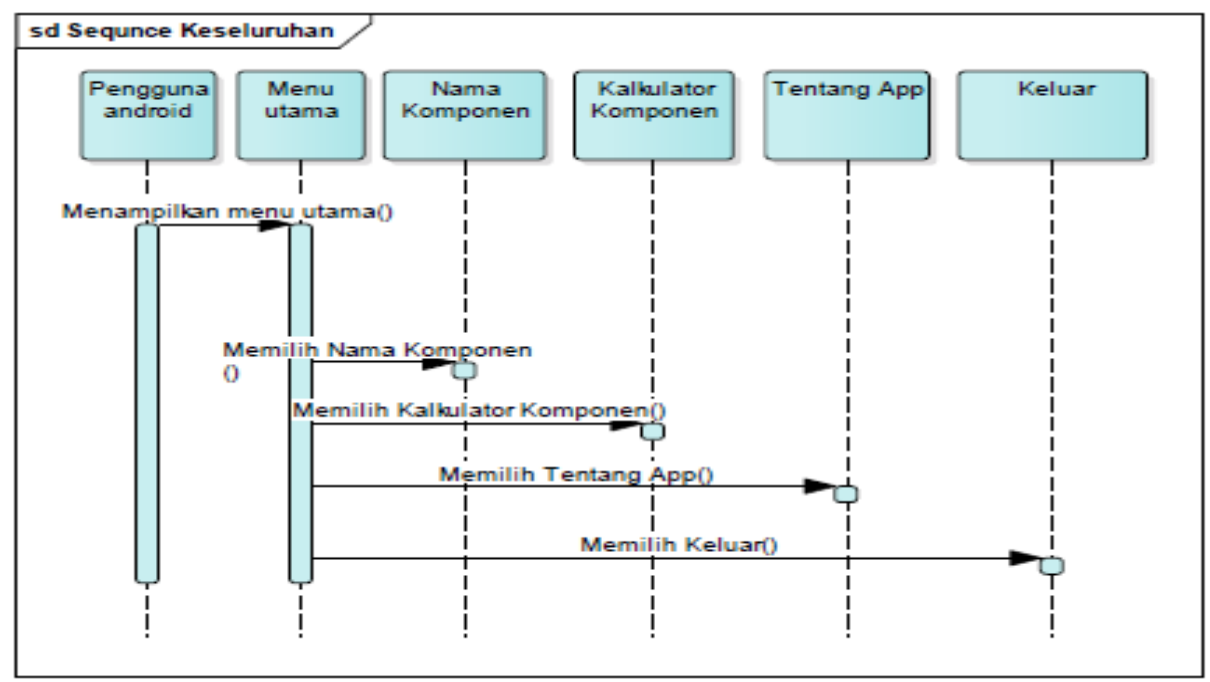

Gambar 4. Sequence Diagram

d. Class Diagram

Berikut merupakan rancangan dari class diagram diagram.

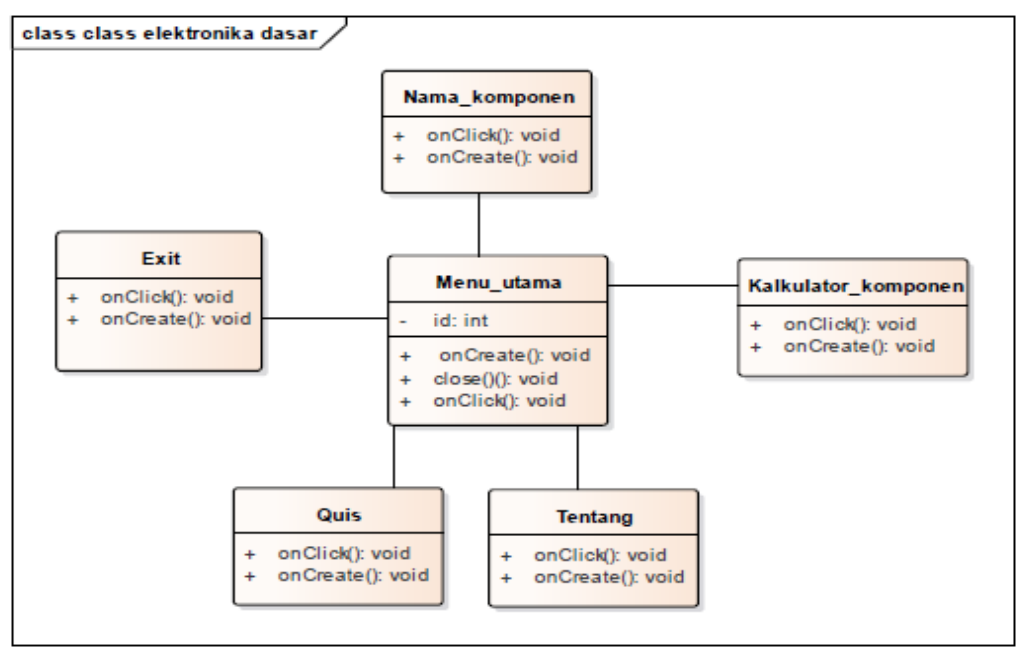

Gambar 5. Class Diagram 


\subsection{Implementasi}

\section{Applicatiton Generation}

a. Menu Utama

Interface dimana terdapat 4 pilihan button yaitu button komponen elektro, button bantuan, button tentang dan button keluar.

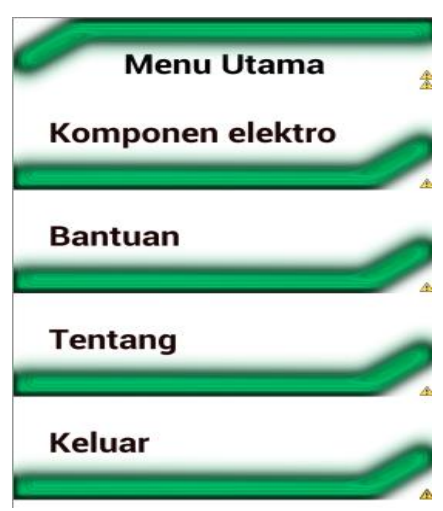

Gambar 6. Menu Utama

b. Menu Kalkulator Resistor

Interface dimana beberapa macam widget seperti button, textview dam lain-lain.

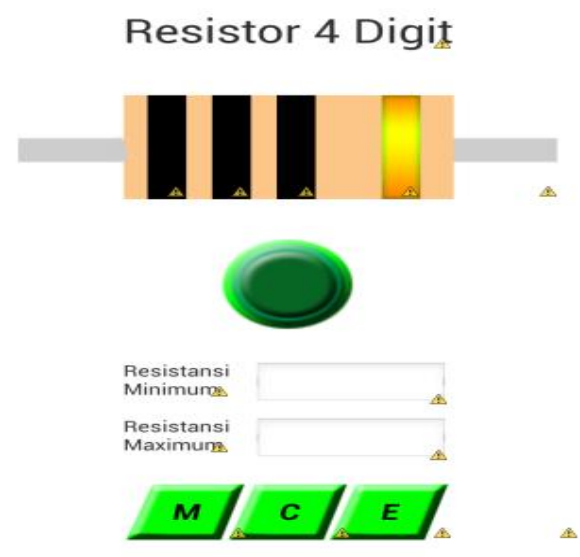

Gambar 7. Kalkulator resistor

c. Menu kalkulator kapasitor mika

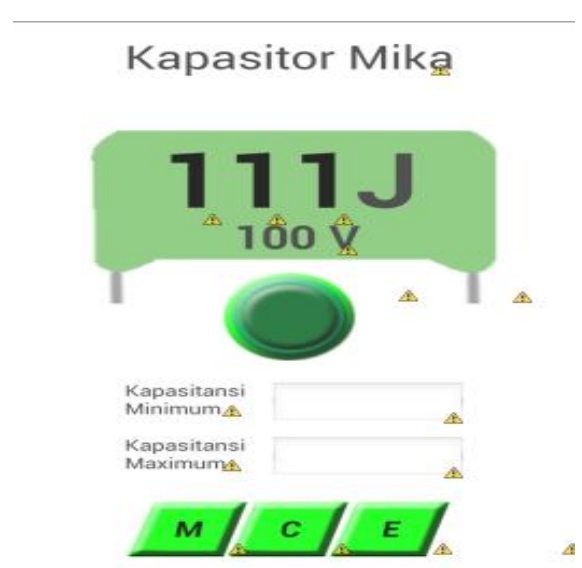

Gambar 8. Menu kalkulator kapasitor mika

\section{Testing and Turnover}

Pada tahap ini penulis melakukan testing atau pengujian terhadap aplikasi yang kami buat yang menggunakan blackbox testing. Adapun hasil dari pengujian blackbox testing ini sebagai berikut: 
Tabel 1. Pengujian Blackbox Resistor

\begin{tabular}{cllll}
\hline No & Skenario Uji & Test Case & Hasil yang diharapkan & Valid \\
\hline 1 & Memilih warna gelang1 & ActionDialogList1( ) & Menampilkan list gelang warna1 & Valid \\
2 & Memilih warna gelang2 & ActionDialogList2( ) & Menampilkan list gelang warna2 & Valid \\
3 & Memilih warna gelang3 & ActionDialogList3( ) & Menampilkan list gelang warna3 & Valid \\
4 & Memilih warna gelang4 & ActionDialogList4( ) & Menampilkan list gelang warna4 & Valid \\
5 & Mengklik Button "Hitungan & Klik Button1 & Menampilkan nilai hambatan & Valid \\
& Hambatan" & Klik Button2 & Menghapus ActionDialogList1( ) & Valid \\
6 & Mengklik Button "Hapus" & & sampai dengan ActionDialogList4( ) & \\
& & & dan menghapus TextView1 dan & \\
\hline
\end{tabular}

\section{KESIMPULAN}

Setelah penulis membuat aplikasi perhitungan komponen pasif elektronika dapat disimpulkan bahwa.

1. Aplikasi yang dibuat penulis membantu pembelajaran elektronika dasar bagi siswa smp, siswa smk jurusan elektronika industri serta mahasiswa jurusan teknik komputer.

2. Aplikasi belum support untuk $O S$ android di atas jelly bean seperti kitkat, dan lolipop.

3. Aplikasi belum support untuk semua layar handphone, dikarenakan dalam pembuatan aplikasinya penulis mengkhususkan untuk ukuran layar dibawah 4,65 inch atau 720x1280:xhdpi.

\section{REFERENCES}

[1] A. Satyaputra and E. M. Aritonang, Java for Beginners with Eclipse 4.2 Juno. Jakarta : Elex media Komputindo, 2012.

[2] B. C. Setiawan Ade, Mulyani Astriani, "Perhitungan Komponen Elektronika Dasar Berbasis Android," J. Techno Nusa Mandiri, vol. XI, 2014.

[3] D. Hariyanto, "Studi Penentuan Nilai Resistor Menggunakan Seleksi Warna Model HSI Pada Citra 2D, " J. Telkomnika, vol. 7, 2009.

[4] I. M. dkk Siregar, Mengembangkan Aplikasi Enterprise Berbasis Android. Gava Media, Yogyakarta, 2010.

[5] M. Sukamto, R. A. Shalahuddin, Rekayasa Perangkat Lunak Terstruktur dan Berorientasi Objek. Bandung: Informatika, 2013.

[6] R. S. Pressman, Rekayasa Perangkat Lunak. Yogyakarta:Andi, 2010.

[7] S. Nazruddin, Pemprograman Aplikasi Mobile Smartphone dan Tablet PC Berbasis Android. Bandung: Informatika, 2011.

[8] Setiawan Ade, “Aplikasi Perhitungan Resistor SMD Berbasis Android,” J. Akrab Juara, vol. 4, 2019. 